\title{
STUDI KELAYAKAN EKONOMI DAN PRODUKSI PEMANFAATAN PAKAN PENGISI DAN PHENOMENA COMPENSATORY GROWTH PADA PETERNAKAN AYAM PEDAGING
}

\author{
F. Trisakti Haryadi dan Wihandoyo
}

\begin{abstract}
INTISARI
Tujuan penelitian adalah menciptakan manajemen pemberian pakan pengisi yang tepat waktu pada ayam pedaging dan phenomena compensatory growth untuk mengatasi penurunan harga jual ayam pedaging dewasa di pasaran, sehingga peternak tidak terlalu rugi. Penelitian menggunakan rancangan acak lengkap pola searah dengan 231 ekor DOC broiler jantan dibagi secara acak dalam 11 perlakuan dengan tiga ulangan setiap perlakuan dan tujuh ekor setiap ulangan. Perlakuan P-0 diberi pakan starter (PS) selama 42 hari (kontrol), P-1 diberi PS selama 28 hari kemudian pakan pengisi (PP) selama tujuh hari dan pakan finisher (PF) selama tujuh hari (28PS+7PP+7PF), P-2 $(21 \mathrm{PS}+7 \mathrm{PP}+14 \mathrm{PF}), \mathrm{P}-3$ (21PS+14PP+7PF), P-4 (14PS+7PP+21PF), P-5 (14PS+14PP+14PF), P-6 $(14 \mathrm{PS}+21 \mathrm{PP}+7 \mathrm{PF}), \mathrm{P}-7$ (7PS+7PP+28PF), P-8 (7PS+14PP+21PF), P-9 (7PS+21PP+14PF), dan P-10 $(7 \mathrm{PS}+28 \mathrm{PP}+7 \mathrm{PF})$. Hasil penelitian menunjukkan perbedaan sangat nyata $(\mathrm{P}<0,01)$ untuk bobot badan, konsumsi pakan, dan FCR, berat dan panjang tulang femur akibat pemberian pakan pengisi. Analisis income over feed cost menunjukkan ada perbedaan sangat nyata $(\mathrm{P}<0,01)$ akibat pemberian pakan pengisi. Berdasarkan hasil penelitian, maka kesimpulan yang diperoleh bahwa pemberian pakan pengisi selama tujuh hari menghasilkan kinerja pertumbuhan; produksi dan tulang femur pada umur 42 hari; dan pendapatan yang menyamai kontrol.
\end{abstract}

(Kata kunci : Pakan pengisi, Compensatory growth, Bobot badan, Konsumsi pakan, Tulang femur, dan Pendapatan).

Buletin Peternakan $29(1): 26-34,2005$

${ }^{\text {IF }}$ akultas Peternakan Universitas Gadjah Mada Yogyakarta. 


\title{
FEASIBILITY STUDY OF THE USE OF STUFFED FEED AND COMPENSATORY GROWTH ON ECONOMICS AND PRODUCTION OF BROILER FARMING
}

\begin{abstract}
The objective of the research was to find out suitable time to use stuffed feed and compensatory growth in overcoming the dropping of broiler price in the market as well as decreasing risks in financial losses burdened farmers. Completely randomized design was applied in the study with 231 DOC male broiler being randomly devided into 11 treatments in three replications with seven chicks each. The dietary treatments were P-0 fed with starter feed (SF) for 42 days (control), P-1 fed with SF for 28 days + stuffed feed (STF) for seven days + finisher feed (FF) for seven days (28SF+7STF+7FF), P-2 (21SF+7STF+14FF $), \quad P-3 \quad(21 \mathrm{SF}+14 \mathrm{STF}+7 \mathrm{FF}), \quad \mathrm{P}-4 \quad(14 \mathrm{SF}+7 \mathrm{STF}+21 \mathrm{FF}), \quad \mathrm{P}-5$ $(14 \mathrm{SF}+14 \mathrm{STF}+14 \mathrm{FF}), \mathrm{P}-6(14 \mathrm{SF}+21 \mathrm{STF}+7 \mathrm{FF}), \mathrm{P}-7(7 \mathrm{SF}+7 \mathrm{STF}+28 \mathrm{FF}), \mathrm{P}-8(7 \mathrm{SF}+14 \mathrm{STF}+21 \mathrm{FF})$, P-9 $(7 \mathrm{SF}+21 \mathrm{STF}+14 \mathrm{FF})$, and $\mathrm{P}-10(7 \mathrm{SF}+28 \mathrm{STF}+7 \mathrm{FF})$. The results showed that stuffed feed treatment had caused significant differences $(\mathrm{P}<0.01)$ on body weight, feed consumption, FCR, length and weight of femur bone. It can be concluded that the use of stuffed feed during seven days resulted in similar growth performance, production and qualities of carcass and femur bone at 42 of age, and the same result was also shown on income over feed cost compared to control.
\end{abstract}

(Key words : Stuffed feed, Compensatory growth, Body weight, Feed consumption, Femur bone, and Income over feed cost).

\section{Pendahuluan}

Keberlanjutan usaha petemakan kecil, terutama usaha ayam pedaging, sangat dipengaruhi oleh faktor fluktuasi harga jual ayam pedaging hidup umur 42 hari dan biaya produksi. Kondisi selama ini menunjukkan bahwa faktor-faktor tersebut sering menyebabkan usaha peternakan ayam pedaging skala menengah ke bawah mengalami kerugian yang cukup besar, bahkan gulung tikar. Peternak tidak dapat meramal dan mengetahui dengan pasti saat mulai dan berakhimya kejadian yang menyebabkan kerugian akibat kedua faktor tersebut.

Kondisi yang serba tidak menentu dan merugikan ini membuat peternak, terutama peternak mandiri, menjadi panik. Kepanikan akan lebih terasa apabila peternak sudah terlanjur melakukan peremajaan ayamnya yakni satu atau dua minggu dengan harga bibit ayam dan pakan yang normal, tetapi kemudian harga ayam pedaging di pasaran mendadak jatuh. Pada kondisi semacam ini, peternak tidak tahu cara yang harus dikerjakan. Walaupun harga ayam jatuh, namun peternak tetap harus memberi pakan pada ayamnya setiap hari. Semakin hari umur ayam makin bertambah dan bobot juga semakin besar, sehingga memerlukan pakan lebih banyak. Harga ayam di pasaran yang tetap rendah mengakibatkan peternak sudah tentu akan mengalami kerugian.

Untuk menekan kerugian yang besar, maka diperlukan adanya manajemen khusus yakni menunda umur jual ayam tanpa harus membebani peternak dengan tambahan biaya pakan tetapi ayam masih tetap dapat tumbuh walaupun lambat. Keterlambatan pertumbuhan diharapkan dapat dikejar dengan memberi pakan pengisi (stuffed feed) yaitu pakan yang diberikan pada ayam, dengan bahan pakan yang mempunyai kandungan nutrient tidak terlalu tinggi kadar protein dan kalorinya. Pakan ini hanya untuk hidup saja selama waktu tertentu sehingga pertumbuhan menjadi lambat. Pakan tersebut dapat berupa dedak halus (Lesson et al. 1991). Setelah pemberian pakan pengisi selesai, maka dilanjutkan dengan pemberian pakan rasional dan apabila perlu ditambah dengan vitamin dan mineral sehingga ayam dapat mengejar pertumbuhan yang telah tertunda (growth recovery). Manajemen khusus ini sebenarnya memanfaatkan fenomena alam yakni compensatory growth. 
Pemberian pakan dengan aras protein dan asam amino rendah selama awal pertumbuhan diikuti pemberian pakan kontrol akan menghasilkan compensatory growth (Palvink and Hurwiz, 1988). Konsep compensatory growth adalah membatasi konsumsi protein dan asam amino selama awal fase pertumbuhan sehingga kenaikan bobot badan akan berkurang. Pengembalian pakan normal pada fase berikutnya menyebabkan kalkun mempunyai bobot pasar mirip kontrol (Oju et al. 1988). Pakan dengan level protein $60 ; 70$; dan $80 \%$ dari rekomendasi NRC (1984) tidak menghasilkan compensatory growth (Ferket and Sell, 1989 $)$, produksi dan kualitas karkas tidak terpengaruh kecuali protein pakan $60 \%$ yang menyebabkan penurunan otot dada (Ferket and Sell, 1989 $)$.

Keuntungan pemberian pakan pada compensatory growth ringan dibandingkan kontrol antara lain menurunkan kasus abnormalitas kaki dan peningkatan protein dibandingkan rasio kenaikan bobot badan dapat menurunkan biaya pakan (Hester et al. 1990). Lebih jauh dinyatakan bahwa rendahnya konsumsi protein dan asam amino dari enam sampai 12 minggu menyebabkan ringannya otot dada pada umur 20 minggu dan compensatory growth tidak berpengaruh mutlak terhadap panjang dan lebar tarsometatarsus atau berat testes pada umur 20 minggu. Efisiensi penggunaan pakan dan reduksi kandungan lemak karkas juga merupakan potensi kelebihan compensatoryklasik (Palvink and Hurwiz, 1988) disamping pertumbuhan yang lambat pada waktu tertentu mungkin juga penting untuk optimalisasi pertumbuhan tulang. Roserbrough et al. (1986) mengamati pengurangan ukuran hati dan lipogenesis ayam umur 12 hari yang diberi pembatasan pakan selama umur enam sampai 12 hari Data produksi hidup seperti karkas yang dihasilkan perlu dipertimbangkan pada evaluasi ekonomi dan uji kelayakan penggunaan phenomena compensatory growth di peternakan kalkun komersial (Hester et al. (1990).

Penelitian ini bertujuan menciptakan manajemen pemberian pakan pengisi yang tepat waktu pada ayam pedaging dan phenomena compensatory growth untuk mengatasi fluktuasi harga jual ayam dewasa (daging) di pasaran sehingga peternak tidak rugi terlalu banyak. Melalui penelitian ini diduga bahwa ayam pedaging mampu mengejar keterlambatan pertumbuhan setelah mendapat perlakukan pakan pengisi beberapa waktu, kemudian dilanjutkan dengan memberi pakan normal dengan memanfaatkan compensatory growth. Penggunaan pakan pengisi yang singkat (tujuh hari) diduga mampu menghasilkan pendapatan yang menyamai kontrol dan lebih tinggi dibandingkan pakan pengisi yang diberikan lebih dari tujuh hari.

\section{Materi dan Metode}

Bahan yang digunakan dalam penelitian ini meliputi 231 ekor anak ayam broiler jantan strain Lohmann umur satu hari. Pakan yang digunakan untuk selama 42 hari adalah pakan starter produksi PT Wonokoyo Pasuruan dengan kandungan $\mathrm{PK}, \mathrm{ME}, \mathrm{Ca}$, dan $\mathrm{P}$ berturut-turut 20 sampai $30 \%, 2900$ sampai $3000 \mathrm{kcal} / \mathrm{kg}, 0,9$ sampai $1,0 \%$, dan 0,4 sampai $0,5 \%$. Pakan lain adalah bekatul sebagai pakan pengisi yang ditambah dengan mineral B-12 produksi Eka Farma Semarang, sehingga kandungan $\mathrm{Ca}$ menjadi $1,03 \%$ dan $P$ sebesar $0,33 \%$. Selain vaksin penyakit ND dan Gumboro (300 dosis), juga digunakan obat anti stress. Peralatan yang dibutuhkan adalah kandang ayam dengan lantai berbilah sebanyak 33 unit, masing-masing dilengkapi tempat pakan dan minum. Timbangan dan seperangkat alat untuk menyembelih ayam serta laboratorium biokimia dengan peralatannya juga dibutuhkan dalam penelitian ini.

Penelitian ini menggunakan rancangan acak lengkap pola searah. Dua ratus tiga puluh satu ekor ayam broiler umur satu hari dibagi secara acak ke dalam 33 kandang (tujuh ekor per kandang). Setiap tiga unit kandang menjadi replikasi untuk setiap perlakuan. Jumlah perlakuan yang dikerjakan ada 11 macam (Tabel 1.).

Data yang dikumpulkan adalah berat badan setiap tujuh hari dengan cara menimbang ayam, konsumsi dan konversi pakan dengan cara menimbang pakan yang disediakan dan 
Tabel 1. Rancangan perlakuan pakan (Design of dietary treatments)

\begin{tabular}{|c|c|c|c|}
\hline \multirow{2}{*}{$\begin{array}{l}\text { Kode perlakuan } \\
\text { (Treatments code) }\end{array}$} & \multicolumn{3}{|c|}{ Perlakuan (Treatments) } \\
\hline & $\begin{array}{c}\text { Pakan starter mu lai } \\
\text { umur (hari) (Starting } \\
\text { age with starter feed } \\
\text { (days)) }\end{array}$ & $\begin{array}{c}\text { Pakan pengisi mulai } \\
\text { umur (hari) (Starting } \\
\text { age with stuffed feed } \\
\text { (days)) }\end{array}$ & $\begin{array}{l}\text { Pakan finisher mulai } \\
\text { umur (hari) (Starting } \\
\text { age with finisher feed } \\
\text { (days)) }\end{array}$ \\
\hline P-0 & $1-42$ & - & - \\
\hline$P-1$ & $1-28$ & $29-35$ & $36-42$ \\
\hline $\mathrm{P}-2$ & $1-21$ & $22-28$ & $29-42$ \\
\hline $\mathrm{P}-3$ & $1-21$ & $22-35$ & $36-42$ \\
\hline$P-4$ & $1-14$ & $15-21$ & $22-42$ \\
\hline $\mathrm{P}-5$ & $1-14$ & $15-28$ & $29-42$ \\
\hline P-6 & $1-14$ & $15-35$ & $36-42$ \\
\hline P-7 & $1-7$ & $8-14$ & $15-42$ \\
\hline P-8 & $1-7$ & $8-21$ & $22-42$ \\
\hline P-9 & $1-7$ & $8-28$ & $29-42$ \\
\hline$P-10$ & $1-7$ & $8-35$ & $36-42$ \\
\hline
\end{tabular}

yang dihabiskan. Berat dan panjang tulang femur, kematian, dan biaya pakan, serta harga ayam per $\mathrm{kg}$ berat hidup juga dikumpulkan dalam penelitian ini.

Analisis kandungan mineral $\mathrm{Ca}$, dan $\mathrm{P}$ tulang femur menggunakan metode AOAC (1984), sedangkan analisis data menggunakan analisis variansi dari rancangan acak lengkap pola searah dengan bantuan program Statistical Anaiysis System (SAS) for Windows Release 6.12. Analisis ekonomi yang digunakan adalah dengan menghitung income over feed cost.

\section{Hasil dan Pembahasan}

Rerata bobot badan pada umur 42 hari menunjukkan perbedaan yang sangat nyata $(\mathrm{P}<0,0 \mathrm{I})$ antar periakuan dan tampak bahwa pada periakuan kontrol ( $\mathrm{P}-0)$ mempunyai rerata bobot badan yang paling berat yaitu 2125,67 g/ekor dan paling ringan pada $\mathrm{P}-10$ seberat $592,40 \mathrm{~g} /$ ekor (Tabel 2.). Ayam yang mendapat nutrien optimal pada umur satu sampai 42 hari menghasilkan bobot badan yang optimal (P-0). Kelompok yang mendapat pakan pengisi hanya selama tujuh hari, baik mulai minggu kelima, keempat, ketiga maupun kedua (P-1, P-2, P-4, dan $\mathrm{P}-7)$ menghasilkan bobot badan pada umur 42 hari sedikit lebih rendah disbanding P-0, namun justru dihasilkan bobot badan yang ideal untuk dipasaran yaitu $1,8 \mathrm{~kg} / \mathrm{ekor}$ (Tabel 2.) dibanding yang mendapat pakan pengisi lebih dari tujuh hari (P-3, P-5, P-6, P-8, P-9, dan P-10), maupun $\mathrm{P}-0$. Hasil ini terjadi seperti dilaporkan oleh Leeson et al. (1991) bahwa kenaikan bobot badan berhubungan dengan derajat pembatasan pakan.

Hasil penelitian memberi petunjuk bahwa makin lama pemberian pakan pengisi berupa bekatul ditambah mineral B-12 sehingga ayam hanya mendapat pakan yang mengandung $8,55 \%$ $\mathrm{PK}, 2930 \mathrm{kcal} / \mathrm{kg} \mathrm{ME}, 1,03 \% \mathrm{Ca}$, dan $0,33 \% \mathrm{P}$, maka terjadi defisiensi makro nutrien PK dan ME (kebutuhan ayam pedaging menurut NRC (1994) adalah PK $23 \%, 3200 \mathrm{kcal} / \mathrm{kg} \mathrm{ME}, 1,00 \%$ $\mathrm{Ca}$, dan $0,45 \% \mathrm{P}$ ). Keadaan ini menyebabkan hambatan pertumbuhan, karena fungsi protein adalah untuk pertumbuhan sel. Semakin lama ayam mendapat pakan pengisi, maka pertumbuhan semakin terhambat.

Pemberian pakan normal setelah pakan pengisi, dimaksudkan untuk memacu sel-sel tubuh melakukan perbaikan (recovery) pertumbuhan, sehingga terjadi kompensasi pertumbuhan (compensatory growth). Pemberian pakan yang mengandung $20-23 \% \mathrm{PK}$ dan 2900-3000 kcal/kg ME mengakibatkan tubuh dapat melakukan kompensasi 
Tabel 2. Pengaruh perlakuan terhadap rerata kinerja ayampedaging (The effect of treatments on the average of broiler chicken performance)

\begin{tabular}{|c|c|c|c|c|}
\hline $\begin{array}{l}\text { Kode perlakuan } \\
\text { (Treatments } \\
\text { code) }\end{array}$ & $\begin{array}{l}\text { Bobot badan } \\
\text { (g/ekor) (Body } \\
\text { weight } \\
\text { (g/chicken)) }\end{array}$ & $\begin{array}{c}\text { Konsumsi pakan } \\
\text { (g/ekor) (Feed } \\
\text { consumption } \\
\text { (g/chicken)) }\end{array}$ & $\begin{array}{c}\text { Feed } \\
\text { Convertion } \\
\text { Ratio }(F C R)\end{array}$ & $\begin{array}{c}\text { Kematian (ekor } / 42 \\
\text { hari) (Mortality } \\
\text { (chicken } / 42 \text { days)) }\end{array}$ \\
\hline P-0 & $2125,67^{\mathrm{a}}$ & $3514,20^{2}$ & $1,98^{26}$ & 0 \\
\hline P-1 & $1692,70^{\mathrm{bc}}$ & $2913,90^{\mathrm{b}}$ & $1,55^{\mathrm{b}}$ & 0 \\
\hline P-2 & $1820,07^{b}$ & $3014,40^{b}$ & $1,87^{\mathrm{ab}}$ & 1 \\
\hline P-3 & $1340,57^{\circ}$ & $2872,50^{b}$ & $1,79^{\text {ab }}$ & 1 \\
\hline P-4 & $1805,00^{\mathrm{b}}$ & $3052,60^{b}$ & $1,97^{\mathrm{ab}}$ & 1 \\
\hline P-5 & $1498,07^{d}$ & $2815,50^{b}$ & $2,33^{a}$ & 0 \\
\hline P-6 & $935,56^{\mathrm{f}}$ & $2487,00^{\circ}$ & $1,93^{\text {ab }}$ & 3 \\
\hline P-7 & $1821,57^{b}$ & $2872,80^{\mathrm{b}}$ & $1,86^{\mathrm{ab}}$ & 1 \\
\hline P-8 & $1637,91^{\mathrm{cd}}$ & $2774,70^{\mathrm{bc}}$ & $2,20^{3}$ & 2 \\
\hline P-9 & $1048,10^{\mathrm{f}}$ & $2073,80^{d}$ & $2,03^{\mathrm{ab}}$ & 3 \\
\hline P-10 & $592,40^{g}$ & $1857,60^{d}$ & $1,96^{\mathrm{ab}}$ & 2 \\
\hline
\end{tabular}

abdels Superskrip yang berbeda dalam ko lom yang same menunjukkan perbedaan yang sangat nyata $(\mathrm{P}<0,01)$ (Different superscript in the same column showed significant differences $(P<0.01)$ ).

pertumbuhan optimal dengan memanfaatkan nutrien yang tersedia. Hal ini terlihat pada kelompok yang mendapat pakan pengisi tidak lebih dari tujuh hari (P-1,P-2, P-4, dan P-7). Pada kelompok yang mendapat pakan pengisi 14 hari ( $\mathrm{P}-3, \mathrm{P}-5$, dan $\mathrm{P}-8$ ), recovery pertumbuhan tidak sebaik kelompok yang mendapat pakan pengisi tujuh hari (Tabel 2). Suatu fenomena yang menarik adalah lama waktu recovery pertumbuhan atau kompensasi pertumbuhan sangat menentukan bobot badan akhir, sehingga pada P-8 (pakan pengisi 14 hari dengan waktu recovery pertumbuhan selama 21 hari) memiliki bobot badan pada umur 42 hari lebih tinggi dibanding $\mathrm{P}-5$ dan $\mathrm{P}-3$ yang masing-masing mempunyai waktu recovery pertumbuhan 14 dan tujuh hari. Fenomena ini juga terjadi pada kelompok yang mendapat pakan pengisi selama 21 hari (P-6 dan P-9). Terlihat pula bahwa P-9, dengan waktu recovery pertumbuhan selama 14 hari, mempunyai bobot badan umur 42 hari lebih berat dibanding P-6 dengan waktu recovery pertumbuhan hanya tujuh hari. Hal ini terjadi, seperti dijelaskan oleh Wilson and Osboum (1960), bahwa kemampuan hewan melakukan recovery, setelah pengurangan pakan, salah satunya tergantung pada pola pemberian pakan kembali.
Recovery pertumbuhan yang paling jelek adalah pada kelompok yang mendapat pakan pengisi selama 28 hari ( $\mathrm{P}-10)$. Hal ini terjadi karena tubuh ayam mendapat pakan sesuai dengan kebutuhan hanya selama tujuh hari yaitu pada hari ketujuh sebelum dan sesudah mendapat pakan pengisi (umur satu sampai tujuh hari dan 35 sampai 42 hari), sehingga tubuh sudah terlanjur lama mengalami defisiensi nutrien dan tubuh kurang waktu untuk melakukan recovery pertumbuhan akibat umur ayam sudah mencapai 42 hari. Recovery pertumbuhan akan optimal jika terhambatnya pertumbuhan akibat pengurangan pakan selama enam hari terus menerus tetapi cenderung kurus dibanding yang mendapat pengurangan pakan lebih singkat (Zubair and Leeson, 1994).

Total konsumsi pakan terbanyak terjadi pada kelompok kontrol (P-0) dan tampak menurun akibat perlakuan pengisi (Tabel 2). Total konsumsi pakan semakin sedikit akibat semakin lamanya pemberian pakan pengisi. Kejadian ini tampak pada kelompok P-10 yang mendapat pakan pengisi selama 28 hari yaitu sebesar $1857,60 \mathrm{~kg} / 42$ hari, disusul kelompok yang mendapat pakan pengisi selama 21 hari ( $\mathrm{P}$ 6 dan P-9) kemudian kelompok yang mendapat pakan pengisi selama tujuh hari yaitu pada P-1, 
P-2, P-4, dan P-7 (Tabel 2.). Penurunan konsumsi pakan selama pemberian pakan pengisi tampaknya sama dengan pembatasan pakan seperti yang dilaporkan Zubair and Leeson (1994) yaitu selama pembatasan pakan akan terjadi peningkatan laju getah perut dan menyumbang pengurangan pakan dan nutrien yang dimakan. Selain itu memberi indikasi bahwa semakin lama ayam mendapat pakan pengisi, maka pertumbuhan jadi terhambat dengan akibat ukuran tubuh juga mengecil dan perkembangan organ tubuh terutama alat pencernakan juga tidak dapat optimal atau mengecil karena kebutuhan pakan dan volume pakan yang dapat ditampung menjadi lebih sedikit.

Pada Tabel 2 juga terlihat bahwa konversi pakan (FCR) kelompok P-1, P-2, P-4, dan P-7 yaitu pada kelompok ayam yang mendapat pakan pengisi selama tujuh hari (mendapat pakan awal dan recovery pertumbuhan relatif lama yaitu 14 sampai 28 hari) mempunyai angka kurang dari 2,00 (berkisar antara 1,55 sampai 1,87 ). Angka ini berbeda tidak nyata dengan kelompok P-0 $(1,98)$. Hal ini memberi gambaran bahwa walaupun bobot badan yang dihasilkan tidak seberat kelompok P-0, namun konsumsi pakan relatif sedikit sehingga kelompok tersebut efisien dalam merubah per kilogram pakan menjadi daging seperti dijelaskan oleh Osboum and Wilson (1960) bahwa keuntungan kompensasi pertumbuhan klasik adalah meningkatkan efisiensi pakan. Kejadian yang menarik adalah bahwa pada kelompok P-1, yaitu ayam yang mendapat pakan pengisi paling singkat (selama tujuh hari) kemudian diikuti waktu recovery pertumbuhan paling singkat (tujuh hari), menghasilkan FCR paling rendah $(1,55)$. Keadaaan yang sama terjadi pada $\mathrm{P}-10$, kelompok yang mendapat pakan pengisi paling lama (28 hari) dengan waktu recovery pertumbuhan paling singkat (tujuh hari), menghasilkan FCR lebih rendah $(1,96)$ dibanding P-0 $(1,98)$. Hal ini memberi petunjuk bahwa ayam mampu melakukan kompensasi pertumbuhan selama tersedia waktu untuk recovery pertumbuhan yang cukup lama (21 sampai 28 hari) dengan mendapat pakan yang kandungan nutriennya sesuai dengan kebutuhan.
Kematian selama 42 hari tampak terjadi bukan karena pengaruh pakan pengisi. Kematian terjadi relatif paling banyak pada P-6 dan P-9 yaitu tiga ekor/42 hari (Tabel 2). Dari hasil pemeriksaan klinik post mortem dikarenakan penyakit ND yang terjadi setelah vaksinasi (post vaccine syndrome). Hasil ini seperti hasil yang dikerjakan oleh Zubair and Leeson (1994) bahwa tidak ada perbedaan kematian selama periode nol sampai 49 hari akibat dari perlakuan variasi waktu dan pembatasan nutrien awal.

Rerata berat tulang femur ayam umur 42 hari menunjukkan perbedaan sangat nyata $(\mathrm{P}<0,01)$ antara kelompok perlakuan (Tabel 3.). Penggunaan pakan pengisi menyebabkan pengurangan berat tulang femur, karena pakan pengisi adalah bekatul walaupun sudah ditambah mineral mix, ternyata mineral dari pakan komersial masih lebih baik dalam menyediakan mineral $\mathrm{Ca}$ dan $\mathrm{P}$, disamping itu diduga ketersediaan mineral $\mathrm{P}$ sangat terbatas karena berasal dari tanaman hanya dapat diabsorbsi tubuh ayam sekitar $60 \%$ sampai $70 \%$ (NRC, 1994) dengan akibat absorbsi Ca juga terganggu karena imbangan Ca:P tidak ideal. Hasil ini terlihat pada kelompok yang mendapat pakan pengisi tujuh hari yaitu tulang femurnya lebih berat dibanding kelompok yang mendapat pakan pengisi lebih dari tujuh hari, sedangkan teringan pada kelompok yang mendapat pakan pengisi selama 28 hari $(\mathrm{P}-10)$ yaitu seberat $2,42 \mathrm{~g}$.

Rerata panjang tulang femur ayam umur 42 hari tampak menunjukkan perbedaan sangat nyata $(\mathrm{P}<0,01)$ antara kelompok perlakuan (Tabel 3.). Kelompok P-0 menghasilkan tulang femur yang paling panjang. Kelompok yang mendapat pakan pengisi selama tujuh hari $(\mathrm{P}-2$, P-4, dan P-7) menghasilkan tulang fermur yang relatif lebih panjang dari pada kelompok yang mendapat pakan pengisi selama 21 atau 28 hari (P-6, P-9, dan P-10). Kondisi ini sama dengan kondisi yang terjadi untuk berat tulang femur, tetapi berlawanan dengan hasil yang dilaporkan oleh Hester et al. (1990) bahwa panjang dan lebar tulang tarsometatarsal kalkun tidak dipengaruhi oleh perlakuan pembatasan pakan dan compensatory growth. Kalkun yang mendapat pakan $74 \%$ dari kontrol selama enam sampai 12 minggu dan dilanjutkan $70 \%$ dari kontrol selama 
Tabel 3. Pengaruh perlakuan terhadap panjang dan berat tulang femur (The effect of treatments on the length and weight of femur bone)

\begin{tabular}{|c|c|c|}
\hline $\begin{array}{c}\text { Kode perla kuan (Trealment } \\
\text { code) }\end{array}$ & $\begin{array}{c}\text { Berat (Femur bone } \\
\text { weight }(\mathrm{g}) \text { ) }\end{array}$ & $\begin{array}{l}\text { Panjang (The length of } \\
\text { femur bone }(\mathrm{cm}) \text { ) }\end{array}$ \\
\hline P-0 & $9,72^{\mathrm{a}}$ & $7,36^{\mathrm{a}}$ \\
\hline P-1 & $7,16^{\mathrm{ed}}$ & $6,66^{\mathrm{bc}}$ \\
\hline P-2 & $8,19^{b}$ & $6,94^{\mathrm{ab}}$ \\
\hline P-3 & $5,92^{\circ}$ & $6,07^{\mathrm{dc}}$ \\
\hline $\mathrm{P}-4$ & $7,01^{\text {ed }}$ & $6,45^{\mathrm{bc}}$ \\
\hline P-5 & $6,28^{\mathrm{de}}$ & $6,16^{c}$ \\
\hline P-6 & $3,47^{r}$ & $5,26^{6}$ \\
\hline P-7 & $8,27^{b}$ & $6,82^{2 \mathrm{~b}}$ \\
\hline P-8 & $7,39^{\mathrm{bc}}$ & $6,85^{\mathrm{ab}}$ \\
\hline P-9 & $3,98^{\mathrm{f}}$ & $5,52^{\mathrm{de}}$ \\
\hline P-10 & $2,42^{\mathrm{g}}$ & $4,75^{\mathrm{f}}$ \\
\hline Probabilit & *** & $* *$ \\
\hline
\end{tabular}

abes Superskrip yang berbeda dalam kolom yang sama menunjukkan perbedaan yang sangat nyata $* *(\mathrm{P}<0,01)$ (Different superscript in the same column showed high significant differences $* *(P<0.01))$.

Tabel 4. Analisis ekonomi pengaruh perlakuan terhadap pendapatan (Economic analysis of the treatments effect on the income over feed cost)

\begin{tabular}{|c|c|c|c|}
\hline $\begin{array}{l}\text { Kode perlakuan } \\
\text { (Treatment code) }\end{array}$ & $\begin{array}{l}\text { Penjualan ayam } \\
\text { (Chicken sold }(R p))\end{array}$ & $\begin{array}{c}\text { Biaya pakan (Feed } \\
\text { cost }(R p))\end{array}$ & $\begin{array}{c}\text { Pendapatan (Income over } \\
\text { feed cost (Rp)) }\end{array}$ \\
\hline $\mathrm{P}-0$ & $13.179,10^{2}$ & $7.277,60^{2}$ & $5.873,30^{2}$ \\
\hline$P-1$ & $10.494,70^{b c}$ & $5.816,80^{\mathrm{bc}}$ & $4.678,00^{\circ d}$ \\
\hline P-2 & $11.284,40^{b}$ & $5.745,70^{b c}$ & $5.538,70^{\mathrm{ab}}$ \\
\hline P-3 & $8.311,50^{\circ}$ & $5.133,80^{d}$ & $3.177,70^{e}$ \\
\hline$P-4$ & $11.191,00^{b}$ & $5.986,40^{b}$ & $5.204,60^{\mathrm{abc}}$ \\
\hline P-5 & $9.288,00^{\mathrm{d}}$ & $4.998,70^{\mathrm{d}}$ & $4.289,30^{d}$ \\
\hline P-6 & $5.800,00^{f}$ & $3.909,30^{\circ}$ & $1.891,30^{f}$ \\
\hline P-7 & $11.293,70^{b}$ & $5.989,50^{b}$ & $5.195,90^{\mathrm{abc}}$ \\
\hline P-8 & $10.155,00^{\mathrm{cd}}$ & $5.329,90^{\text {ed }}$ & $4.825,10^{b c d}$ \\
\hline P-9 & $6.498,20^{f}$ & $3.485,20^{\circ}$ & $3.013,20^{c}$ \\
\hline$P-10$ & $3,692,90^{\circ}$ & $2.795,20^{r}$ & $897,60^{\circ}$ \\
\hline
\end{tabular}

abđers Superskrip yang berbeda dalam ko lom yang sama menunjukkan perbedaan yang sangat nyata $(\mathrm{P}<0,01)$ (Different superscript in the same column showed high significant differences $(P<0.01)$ ).

12 sampai 20 minggu mempunyai shank lebih panjang dibanding kontrol.

Hasil perhitungan ekonomi sederhana (income over feed cost) menunjukkan bahwa pendapatan sangat tergantung dari bobot badan yang dicapai dan total konsumsi pakan sampai umur 42 minggu. Kelompok P-0 masih memberikan pendapatan tertinggi, namun jika dilihat dari bobot hidup yang dicapai, maka akan mendapat kesulitan dalam menjualnya karena ayam sudah mencapai bobot 2125,67 g/ekor (Tabel 2). Pemberian pakan pengisi selama tujuh 
hari (P-2, P-4, dan $\mathrm{P}-7$ ) menghasilkan pendapatan yang tidak nyata jika dibandingkan dengan P-0 (Tabel 4). Hal ini disebabkan karena total biaya pakan kelompok P-2, P-4, dan P-7 jauh lebih rendah jika dibandingkan P-0 karena pakan pengisi hanya bekatul, namum selanjutnya pemberian pakan pengisi selama lebih dari tujuh hari akan menghasilkan pendapatan yang terus menurun walaupun biaya pakan menurun. Keadaan ini dapat dijelaskan bahwa lamanya ayam kekurangan nutrien yang diperlukan tubuhnya mengakibatkan hambatan pertumbuhan lebih lama, sehingga untuk recovery pertumbuhannyapun perlu waktu lama dengan akibat bobot badan pada umur 42 hari relatifkecil.

\section{Kesimpulan dan Saran}

Berdasarkan hasil penelitian dan pembahasan mengenai studi kelayakan ekonomi dan produksi pemanfaatan pakan pengisi dan phenomena compensatory growth pada peternakan ayam pedaging, maka dapat diambil kesimpulan sebagai berikut:

1. Pemberian pakan pengisi menghasilkan penurunan yang nyata terhadap bobot badan ayam umur 42 hari dan konsumsi pakan, namun cenderung meningkatkan konversi pakan, dan kematian tidak terpengaruh selama percobaan.

2. Berat dan panjang tulang femur ayam umur 42 hari cenderung menurun secara nyata akibat pemberian pakan pengisi, sedangkan berat jenis tulang femur cenderung tidak dipengaruhi oleh pakan pengisi.

3. Pemberian pakan pengisi pada pemeliharaan ayam pedaging cenderung menurunkan secara nyata terhadap pendapatan pada ayam umur 42 hari.

4. Pemberian pakan pengisi selama tujuh hari menghasilkan pendapatan yang menyamai kontrol.

Penggunaan pakan pengisi selama tujuh hari memberikan harapan dalam menyelesaikan masalah fluktuasi harga pakan dan ayam hidup pada peternak, maka masih diperlukan penelitian lebih mendalam terutama lama (waktu) yang tepat untuk memulai dan mengakhiri pemberian pakan pengisi, dan perlu juga diteliti jenis bahan pakan pengisi serta kandungan nutrien ( $\mathrm{PK}, \mathrm{ME}$, $\mathrm{Ca}, \mathrm{P}$, SK, dan lemak) agar dapat direkomendasikan dan nantinya dengan mudah dapat dikerjakan oleh peternak.

\section{Daftar Pustaka}

AOAC. 1984. Official Methods of Analysis. 14 ed. Association of Official Analysis of Chemistry. Arlington.

Cherry, J. A., W. J. Swartworth, and P. B. Seigel. 1984. Adipose Cellularity Studies in Commercial Broiler Chicks. Poult. Sci. 63:97-108.

Ferket, P. R. and J. 1. Sell. 1989 . Effect of Severity of Early Protein Restriction on Large Turkey Toms. 1. Performance Characteristics and Leg. Weakness. Poult. Sci. 68:676-686.

Ferket, P.R. and J.I. Sell. 1989 ${ }^{\mathrm{b}}$. Effect of Severity of Early Protein Restriction on Large Turkey Toms. 2. Carcass Characteristics and Leg Weakness. Poult Sci. 68:676-686.

Hester, P. Y., K. K. Krueger, and M. Jackson. 1990. The Effect of Compensatory Growth on Carcass Characteristics of Male Turkeys. Poult. Sci, 69:1743-1748.

Leeson, S., J. D. Summers, and L. J. Caston. 1991. Diet Dilution and Compensatory Growth in Broilers. Poult. Sci. 70:867873.

NRC. 1994. Nutrient Requirements of Poultry. $9^{\text {th }}$ rev. ed. National Academy Press. Washington.

Oju, E. M., P. E. Waibel, and S. L. Noll. 1988. Early Protein Undernutrition and Subsequent Realimentation in Turkeys. 1. Effect of Performance and Body Composition. Poult. Sci. 67:1750-1759.

Osboum, D. F. and P. N. Wilson. 1960. Effect of Different Patterns of Allocation of Restricted Quantity of Food upon The Growth and Development of Cockerels. J. Agric. Sci. (Camb) 54:278-289.

Palvink, L. and Hurwiz. 1988. Early Feed Restriction in Male Turkeys: Growth Pattern, Feed Efficiency, and Body 
Composition. Poult. Sci. 67:1407-1413.

Rosebrough, R. W., N. C. Steele, J.P. McMurtry, and I. Plavnik. 1986. Effect of Early Feed Restriction in Broilers. II. Lipid Metabolism. Growth. 50:217-227.

Wilson, P. N. and D. F. Osboum. 1960. Compensatory Growth
After
Undernutrition in Mammals and Bird. Biol. Rev. 35:325-363.

Zubair, A. K. and S. Leeson. 1994. Effect of Varying Period of Early Nutrient Restriction on Growth Compensation and Carcass Characteristics of Male Broilers. Poult. Sci. 73:129-136. 